\title{
Role of Phoenix dactylifera in ameliorating Eimeria papillata-induced hepatic injury in mice
}

\author{
Mahmoud S. Metwaly ${ }^{1}$, Mohamed A. Dkhil ${ }^{1,2 \star}$ and Saleh Al-Quraishy ${ }^{1}$ \\ ${ }^{1}$ Department of Zoology, College of Science, King Saud University, Riyadh, Saudi Arabia. \\ ${ }^{2}$ Department of Zoology and Entomology, Faculty of Science, Helwan University, Cairo, Egypt. \\ Accepted 12 January, 2012
}

\begin{abstract}
Phoenix dactylifera (Date) is used in traditional medicine for its pharmacological properties. Here, we investigated the effects of Kodary date fruit on the outcome of coccidiosis caused by Eimeria papillata in mice. Coccidiosis was induced by infection of mice with $1.5 \times 10^{3}$ sporulated oocysts of $E$. papillata. The aqueous extract of date fruit $(4 \mathrm{ml} / \mathrm{kg})$ was used in vivo for its hepatoprotective properties. Anticoccidial and anti-inflammatory activities of date fruit were determined through oocyst output and liver histopathology, respectively. The data showed that mice infected with $E$. papillata revealed an output of about $8.7 \times 10^{3}$ oocysts per gram faeces on day 4 post -inoculation (p.i.). This output significantly decreased to about $6.7 \times 10^{3}$ oocysts in date fruit-treated mice. Infection caused a marked liver injury as indicated by histopathological alterations as well as the significant increase in liver glutamic pyruvate transaminase (GPT) and alkaline phosphatase (ALP). Also, infection induced a significant increase in total protein and total lipids. The aqueous extract of $P$. dactylifera fruit showed a significant $(P \leq 0.05)$ hepatoprotective potential by improving the aforementioned parameters. Based on these results, it is concluded that date fruit could offer protection against hepatotoxicity as well as ameliorate preexisting liver damage.
\end{abstract}

Key words: Date fruit, liver, Eimeria papillata, mice.

\section{INTRODUCTION}

Coccidiosis is a world wide spread disease; it is caused by a protozoan parasite belonging to genus Eimeria (Mehlhorn, 2001). Such parasite has a great economic importance as it causes severe reduction in meat and milk production and death of domestic agriculture animals (Schito and Barata, 1997). Symptoms of such disease include enteritis with severe diarrhoea and weight depression due to mucosal membrane destruction (Jithendran and Bhat, 1996). Rupture of the intestinal wall is associated with increased malnutrition and disturbance of food digestion and absorbance (Baker, 2007; Taylor et al., 2007) leading finally to death and huge economic losses in industrial animal farms (Licois, 2004; Metwaly et al., 2011). The coccidial parasites are characterized by fast reproduction leading to infection especially of young animals (Pakandl et al., 2006). The jejunum tissue

*Corresponding author. E-mail: mohameddkhil@yahoo.com. Tel: 0096614675754 . Fax: 0096614678514. infected with Eimeria papillata has been described to undergo a series of pathological and structural changes (Chobotar et al., 1993), which have been largely ascribed to the inflammatory response of the host. Recently, we have found in E. papillata infections of mice that the inflammatory response of the host is not only confined to the final target site of the intestine (Dkhil et al., 2011a), but is even more pronounced in the liver, though the liver is not a direct target site of E. papillata (Dkhil et al., 2011b).

Similar data was shown in case of Eimeria coecicola infection in rabbits (Al-Quraishi et al., 2011). On the other hand, some information is available that microbial and food antigens derived from the intestine can reach the liver through the hepatic portal system and can elucidate inflammatory and immune responses in the liver (Nagura and Sumi, 1988). Phoenix dactylifera, commonly known as date palm, is considered to be one of the oldest cultivated trees in the world (Al-Taher, 2008). It is an important plant in the regions of Southwest Asia and Northern Africa (Al-Farsi and Lee, 2008). 
The fruit which is the most edible part of the tree as a perfect source of nutrition as low cost food and is an integral part of Arabian diet (Baliga et al., 2011). Its extract was found to exhibit strong antimicrobial activity against various types of microorganisms such as, bacteria (Saddiq and Bawazir, 2010), fungi (Shraideh et al., 1998) and viruses (Jassim and Naji, 2010). Also, date palm extract was found to have a strong hepatoprotective activity against various harmful toxicants (Saafi et al., 2011; Al-Qarawi et al., 2005) from results obtained from histological and biochemical measurements. The present study has been designed to investigate the ameliorative effect of date fruit extract on the hepatic injury-mediated by the intestinal coccidian parasite, E. papillata.

\section{MATERIALS AND METHODS}

\section{Animals}

Swiss albino mice were bred under specified pathogen-free conditions and fed a standard diet and water ad libitum. The experiments were performed only with female mice at an age of 9 to 11 weeks and were approved by state authorities and followed by Saudi Arabian rules for animal protection.

\section{Infection of mice}

A self-healing strain of $E$. papillata was kindly provided by Prof. Mehlhorn (Heinrich Heine University, Duesseldorf, Germany). We maintained E. papillata in naturally infected mice, collected oocysts from feces, surface-sterilized the oocysts with sodium hypochlorite and washed at least four times with sterile saline before oral inoculation as described by Schito et al. (1996). These oocysts were used to inoculate mice by oral gavaging each mouse with $1.5 \times 10^{3}$ sporulated oocysts of $E$. papillata suspended in $100 \mu \mathrm{l}$ sterile saline. Once every $24 \mathrm{~h}$, fresh faecal pellets were collected and weighed for each mouse and the bedding was changed to eliminate reinfection. Oocyst output was measured as previously described (Schito et al. 1996). Faecal pellets were suspended in $2.5 \%(\mathrm{wt} / \mathrm{vol})$ potassium dichromate and diluted in saturated sodium chloride for oocyst flotation. Oocysts were counted in a McMaster chamber and expressed as number of oocysts per gram of wet faeces.

\section{Preparation of aqueous extract of date palm fruit}

Khodary date palm fruits were collected from the markets in Riyadh, Saudi Arabia. Botanical identification of fruits was made in the department of food engineering at College of Food and Agriculture Sciences, King Saud University. The collected fruits were grinded as powder granules according to previously described method (Sablani et al., 2008).

Twenty grams of the produced powder were mixed with $100 \mathrm{ml}$ distilled water (Abu-Elteen, 2000) and filtered from insoluble impurities, sonicated under vacuum and then the separated extract were stored in a refrigerator.

\section{Experimental design}

Three groups of mice, with 6 animals per group, were investigated. The first group was inoculated only with sterile saline and served as the control group. The second group was treated by oral gavaging with $1.5 \times 10^{3}$ sporulated $E$. papillata oocysts. The third group was orally inoculated with $1.5 \times 10^{3}$ sporulated E. papillata oocysts and after $1 \mathrm{~h}$ treated with (20\%) aqueous extract of date palm in a dose of $4 \mathrm{ml} / \mathrm{kg}$ and the dose was repeated for four successive days. The dose and the route of injection were selected on the basis of the previous studies (Al-Qarawi et al., 2005; Saafi et al., 2011).

\section{Histological analysis}

Pieces of liver were freshly prepared, fixed in $10 \%$ neutral buffered formalin and then embedded in paraffin. Sections were cut and then stained with hematoxylin and eosin. Histological damages were scored as follows: 0 : abscent; +: mild; ++; moderate; and +++: severe.

\section{Biochemical analysis}

Animals were cervically dislocated on day 4 p.i. and blood was collected into heparinized tubes, plasma was separated and kept at $-20^{\circ} \mathrm{C}$ until use. Plasma was then analyzed using commercial kits (Biomerieux, Marcy l'Etoil, France) for GPT (Bergmeyer, 1985), ALP (Epstein et al., 1986), glucose (Trinder, 1969a), total cholesterol (Trinder, 1969b), High-density lipoprotein (HDL)cholesterol (Trinder, 1969b) and triglycerides (Fossati and Principe, 1982). Absorbance was measured using the Ultrospec 2000 Ultraviolet (U/V) spectrophotometer (Amersham, Pharmacia Biotech, Cambridge, England). Low-density lipoproteincholesterol (LDL-C) and Very Low Density Lipoprotein-Cholesterol (VLDL-C) were calculated according to Van Horn (1988).

Plasma protein electrophoresis using sodium dodecyl sulphate-polyacrylamide gel electrophoresis (SDS-PAGE)

Plasma samples were subjected to SDS-PAGE according to the method previously described (Laemmli, 1970) using $1.5 \mathrm{~mm} \times 10$ $\mathrm{cm}$ polyacrylamide slab gels consisting of $10 \%$ resolving gel. A volume of 4.5 ul plasma protein samples was mixed with $0.1 \%$ bromophenol blue containing 5\% SDS, $20 \%$ glycerol and $10 \%$ mercaptoethanol. The process was carried out at constant amperage of $20 \mathrm{~mA}$ until the tracking dye was within 1 to $2 \mathrm{~mm}$ from the bottom of the resolving gel. Electrophoresis, gels were stained with Coomassie brilliant blue R-250 (0.15\%) including 50\% methanol and $10 \%$ acetic acid and destained in a mixture of $25 \%$ methanol, $10 \%$ acetic acid and distilled water until no background was detectable. Gel images were taken and analyzed to determine the relative protein content using the Quantity One computer program (version 4.6.5, Bio-Rad, USA).

\section{Statistical analysis}

One-way ANOVA was carried out and the statistical comparisons among the groups were performed with Duncan's test using a statistical package program (SPSS version 17.0). All $p$ values are two-tailed and $P<0.05$ was considered as significant for all statistical analysis in this study.

\section{RESULTS}

The effect of date fruit extract on the outcome of $E$. papillata infections was investigated. During the first 3 days of infection, there was no fecal output of oocysts. On day 4 p.i., the output differed between date fruittreated and non-treated mice. In the latter, the number of 
Table 1. Oocyst output and weight of mice infected with E. papillata.

\begin{tabular}{lcc}
\hline Group & Oocyst output $\times \mathbf{1 0 ^ { 3 }} / \mathbf{g}$ faeces & Weight change in gram \\
\hline Non infected (- Date) & - & $0.85 \pm 0.3$ \\
Infected (- Date) & $8.7 \pm 0.5$ & $-1.7 \pm 0.5^{\mathrm{a}}$ \\
Infected (+ Date) & $6.7 \pm 0.4^{\mathrm{b}}$ & $-0.3 \pm 0.1^{\mathrm{ab}}$ \\
\hline
\end{tabular}

Values are means $\pm S D$. a: Significant against non-infected (- Date) group at $P \leq 0.05$, b: Significant against infected (- Date) group at $p \leq 0.05$.
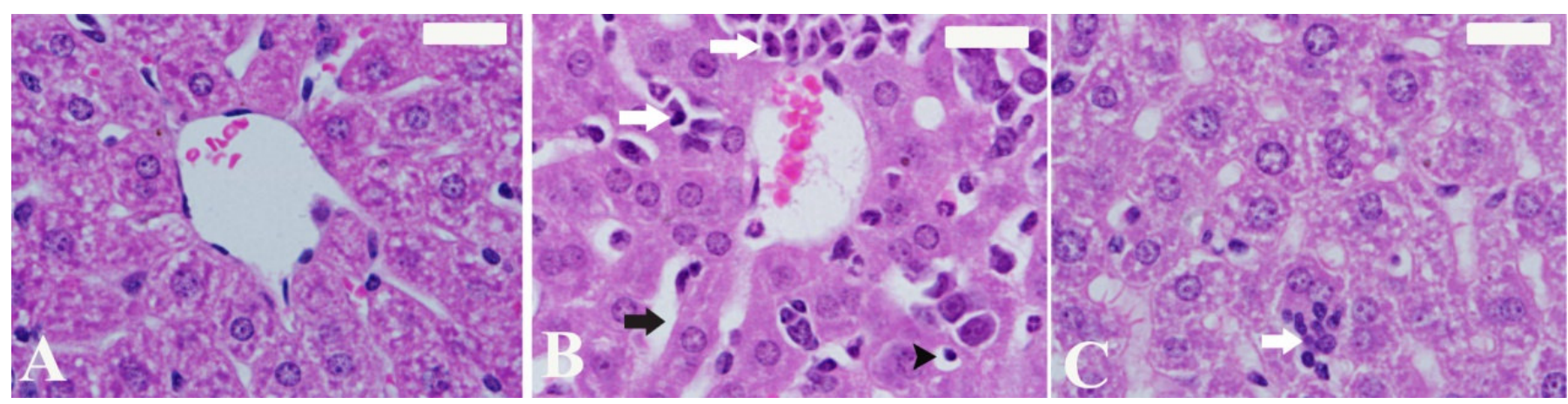

Figure 1. Date fruit improved the hepatic histopathological alterations induced by E. papillata on day 4 p.i.; A, Non-infected liver with normal architectures; B, Infected liver with E. papillata with inflammatory cells (white arrow), apoptotic body (arrow head) and widened sinusoids (black arrow); C, infected-treated liver with some interlobular inflammatory infiltrations. Sections stained wit hematoxylin and eosin. Bar $=25 \mu \mathrm{m}$.

excreted oocysts reached approximately, $8.7 \times 10^{3}$ per gram feces (Table 1). However, the date fruit extract treatment significantly lowered the shedding of oocysts to about $6.7 \times 10^{3}$ oocyst per gram faeces on day 4 p.i. (Figure 2). Concomitantly, the average weight of mice significantly decreases $(p<0.01)$. This weight loss is associated with watery mucoid diarrhea and decreased uptake of water and food. Date fruit was able to lower this weight loss due to infection (Table 1).

The liver has undergone some moderate pathological changes such as inflammatory cellular infiltrations, hepatocytic vacuolations, sinusoid dilatations and edematous hepatocytes in comparison to livers of uninfected mice (Figure 1 and Table 2). Histological analysis revealed that mice infected with sporulated oocysts of $E$. papillata suffered a moderate inflammatory injury in the liver (Figure 1 and Table 2). This injury was diminished when mice were treated with date fruit (Figure 1 and Table 2).

E. papillata infections also induced a significant increase in GPT and ALP (Figure 2). Again, Date fruit extract treatment significantly lowered the $E$. papillatainduced increase in both GPT and ALP, respectively (Figure 2). Table 3 and Figure 3 summarize the electrophoretic protein pattern of mice infected with $E$. papillata and the alterations induced after date fruit treatment. The total protein was significantly increased by the infection. This increased was lowered by date fruit treatment. The albumin/globulin ratio was significantly lowered due $E$. papillata infection and became more significantly decreased when the infected mice was treated with date extract (Table 3 and Figure 3 ). E. papillata was able to change the lipid profile of mice where the total cholesterol reached $167.6 \pm 2.8 \mathrm{mg} / \mathrm{dl}$ compared to $147.7 \pm 5.3 \mathrm{mg} / \mathrm{dl}$ in the non-infected mice. Date fruit extract could significantly decrease the level of cholesterol to be $158.7 \pm 8.4 \mathrm{mg} / \mathrm{dl}$. Triglycerides, LDL and VLDL were significantly increased by the infection (Table 4). Date extract improved the changes in these parameters (Table 4). HDL was significantly decreased $(15.1 \pm 1.4 \mathrm{mg} / \mathrm{dl})$ compared to the non-infected controls $(27.6 \pm 3.4 \mathrm{mg} / \mathrm{dl})$.

\section{DISCUSSION}

The liver is the first-pass organ which is directly connected with the intestine by the portal vein. $E$. papillata parasites infect the distal small intestine and normally do not invade the liver, though different lymphoid organs such as spleen and lymph nodes have been described to be infected by E. coecicola parasites (Renaux et al., 2001). Our data indicate that the 
Table 2. Histopathological changes in hepatic tissue of mice infected with E. papillata and treated with date fruit.

\begin{tabular}{|c|c|c|c|c|c|c|c|c|}
\hline \multirow{3}{*}{ Group } & \multicolumn{8}{|c|}{ Microscopic observation } \\
\hline & \multirow{2}{*}{ Apoptosis } & \multirow{2}{*}{ Haemorrhage } & \multirow{2}{*}{$\begin{array}{c}\text { Disorganized } \\
\text { sinusoids }\end{array}$} & \multicolumn{2}{|c|}{ Lymphocytic infiltration } & \multirow{2}{*}{$\begin{array}{l}\text { Kuppfer cell } \\
\text { hyperplasia }\end{array}$} & \multirow{2}{*}{$\begin{array}{c}\text { Hepatocytic } \\
\text { swelling }\end{array}$} & \multirow{2}{*}{ Steatosis } \\
\hline & & & & Central & Intrlobular & & & \\
\hline Non-Infected (-Date) & + & 0 & 0 & 0 & 0 & 0 & 0 & 0 \\
\hline Infected (-Date) & + & + & ++ & + & +++ & ++ & ++ & +++ \\
\hline Infected (+Date) & + & + & + & +++ & +++ & +++ & + & + \\
\hline
\end{tabular}

0 , Abscent, +, mild, ++, moderate; +++, severe.

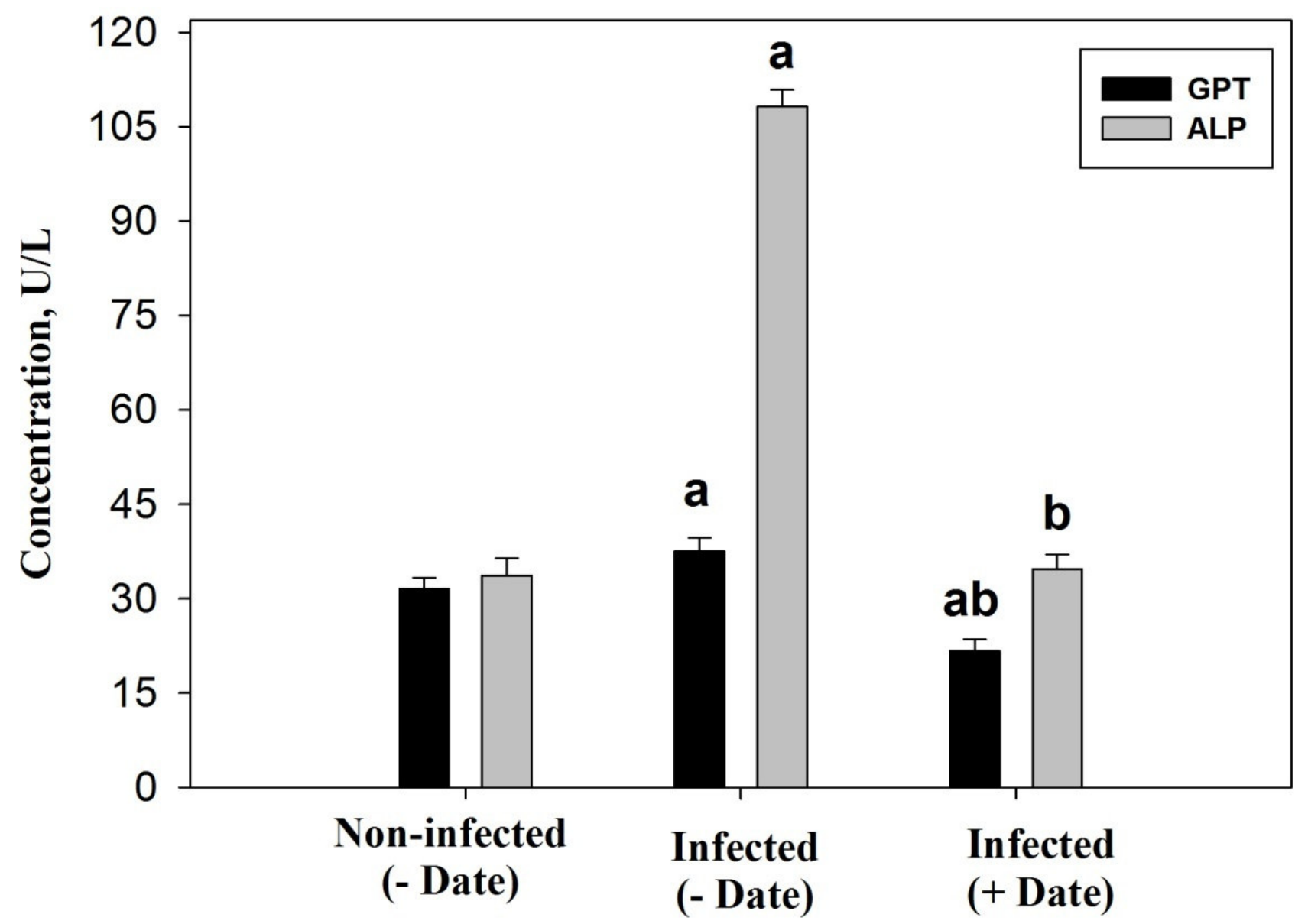

Figure 2. Effect of date fruit on the level of plasma GPT and ALP of mice infected with E. papillata. Values are means \pm SD. Values are means \pm SD. a: Significant against non-infected (- Date) group at $P \leq 0.05$, b: Significant against infected (- Date) group at $P \leq 0.05$.

inflammation of the intestine induced by $E$. papillata is also associated with an inflammatory response of the liver without being directly affected by the parasite (Dkhil et al., 2011b). Moreover, our study shows that date fruit does not only target Eimeria parasites in hosts, but also exhibits antiinflammatory activity thus protecting host tissues. Indeed, E. papillata infections cause an inflammatory response in the hepatic tissue of mice due to the abundance of leucocytes, in general, and lymphocytes, in particular as a prominent response of body tissues facing any injurious impacts. Also, the cytoplasmic vacuolation which is mainly a consequence of considerable disturbances in lipid inclusions and fat metabolism occurring under pathological cases were prominent in hapatocytes. Also, there was a significant increase activity of GPT and ALP. 
Table 3. Date fruit induced alterations in plasma proteins of mice infected with E. papillata.

\begin{tabular}{lccccccc}
\hline Group & $\begin{array}{c}\text { Total } \\
\text { proteins (\%) }\end{array}$ & $\begin{array}{c}\text { Albumin } \\
(\%)\end{array}$ & $\begin{array}{c}\boldsymbol{\alpha} \text { 1- Globulin } \\
(\%)\end{array}$ & $\begin{array}{c}\boldsymbol{\alpha} \text { 2- Globulin } \\
(\%)\end{array}$ & $\begin{array}{c}\boldsymbol{\beta} \text {-Globulin } \\
(\%)\end{array}$ & $\begin{array}{c}\text {-Globulin } \\
(\%)\end{array}$ & A/G Ratio \\
\hline Non -Infected (-Date) & $7.1 \pm 0.2$ & $43.4 \pm 3.2$ & $1.87 \pm 0.09$ & $11.57 \pm 0.7$ & $14.47 \pm 1.1$ & $28.6 \pm 1.2$ & $1.5 \pm 0.01$ \\
Infected (-Date) & $8.9 \pm 0.3^{\mathrm{a}}$ & $43.4 \pm 2.7$ & $2.22 \pm 0.1^{\mathrm{a}}$ & $12.52 \pm 1.05$ & $8.92 \pm 0.95^{\mathrm{a}}$ & $32.95 \pm 2.3^{\mathrm{a}}$ & $1.32 \pm 0.02^{\mathrm{a}}$ \\
Infected (+Date) & $7.8 \pm 0.2^{\mathrm{b}}$ & $32.1 \pm 1.7^{\mathrm{ab}}$ & $1.36 \pm 0.1^{\mathrm{ab}}$ & $17.43 \pm 1.4^{\mathrm{b}}$ & $15.17 \pm 1.1^{\mathrm{ab}}$ & $33.91 \pm 0.9^{\mathrm{ab}}$ & $0.95 \pm 0.01^{\mathrm{ab}}$ \\
\hline
\end{tabular}

Values are means \pm SD. a: Significant against non-infected (- Date) group at $P \leq 0.05$, b: Significant against infected (- Date) group at $P \leq 0.05$.

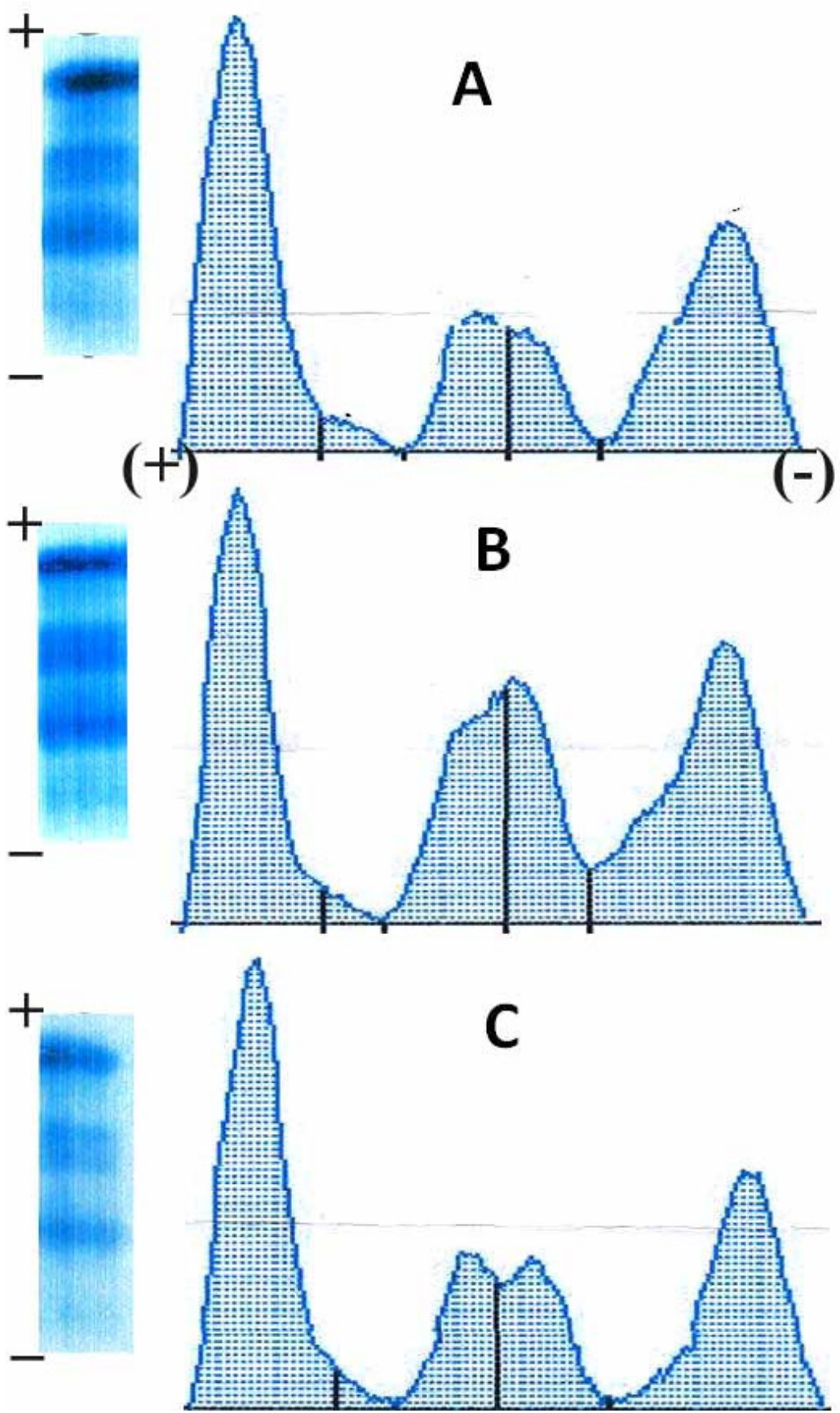

Figure 3. Plasma protein electrophoretogram of mice; A, Non-infected control mice; $\mathbf{B}$, infected mice with $E$. papillata; $\mathbf{C}$, infected-treated mice with date fruit. 
Table 4. Date fruit induced changes in plasma lipids of mice infected with E. papillata.

\begin{tabular}{lccccc}
\hline Group & Total cholesterol (mg/dl) & Total glycerides (mg/dl) & HDLc (mg/dl) & LDLc (mg/dl) & VLDLc (mg/dl) \\
\hline Non -Infected (-Date) & $147.7 \pm 5.3$ & $80.8 \pm 8.8$ & $27.6 \pm 3.4$ & $102.8 \pm 8.4$ & $17.1 \pm 0.2$ \\
Infected (-Date) & $167.6 \pm 2.8^{\mathrm{a}}$ & $124.6 \pm 7.7^{\mathrm{a}}$ & $15.1 \pm 1.4^{\mathrm{a}}$ & $127.2 \pm 3.3^{\mathrm{a}}$ & $25.4 \pm 0.9^{\mathrm{a}}$ \\
Infected (+Date) & $158.2 \pm 8.4^{\mathrm{ab}}$ & $125.2 \pm 2^{\mathrm{a}}$ & $45.2 \pm 3.6^{\mathrm{ab}}$ & $88.1 \pm 6.1^{\mathrm{ab}}$ & $25.4 \pm 0.3^{\mathrm{a}}$ \\
\hline
\end{tabular}

Values are means \pm SD. a: Significant against non-infected (- Date) group at $P \leq 0.05$, b: Significant against infected (- Date) group at $p \leq 0.05$.

Previous studies have shown increased activities of GPT, GOT and ALP (San Martin-Nun ez et al., 1988) due to cholestasis in rabbits suffering from hepatic coccidiosis (Joyner et al., 1983). Neem significantly diminishes liver injury and inflammation and therefore can be considered as a hepatoprotective agent. Also, cholisterol and triglycerides levels in plasma of mice were significantly increased with the infection with E. papillata. However, date fruit was able to decrease their levels (Mard et al., 2010). The initial hope underlying the present experiment was to found a natural product with anticoccidial properties that could be used as a feed additive with minimal processing. Date fruit exhibits anticoccidial activity, evidenced as a significant lowering in the output of $E$. papillata oocysts with the faeces of the infected mice. This diminished output reflects that neem impairs the development of parasites in the host before the relatively inert oocysts are formed and finally released. The fact that date fruit possesses anticoccidial activity has been also reported in chicken coccidiosis (Toula et al., 2010). The present data indicate that date fruit exhibits a significant anticoccidial activity and coincidently, a significant improvement in histopathological picture of the liver and protect the host tissue from injuries induced by parasites.

\section{ACKNOWLEDGMENT}

The authors extend appreciation to the Deanship of Scientific Research at King Saud University for funding the work through the research group project No. RGPVPP-002.

\section{REFERENCES}

Abu-Elteen KH (2000). Effects of date extract on adhesion of Candida species to human buccal epithelial cells in vitro. J. Oral Pathol. Med., 29: 200-205.

Al Farsi MA, Lee CY (2008). Nutritional and functional properties of dates: a review. Crit. Rev. Food Sci. Nutr., 48: 877-887.

Al-Qarawi AA, Abdel-Rahman H, Ali BH, Mousa HM, El-Mougy SA (2005). The ameliorative effect of dates (Phoenix dactylifera L.) on ethanol-induced gastric ulcer in rats. J. Ethnopharmacol., 98: 313317.

Al-Quraishi S, Metwaly MS, Dkhil MA, Abdel-Baki AS, Wunderlich F (2011). Liver response of rabbits to Eimeria coecicola infections. Parasitol. Res. In Press.

Al-Taher AY (2008). Possible anti-diarrhoeal effect of the date palm
(Phoenix dactylifera L.) spathe aqueous extract in rats. Sci. J. King. Faisal. Univ., 9: 131-138.

Baker DG (2007). In: Flynn's parasitology of laboratory animals, $2^{\text {nd }}$ edn. Blackwell, Ames, p. 840.

Baliga MS, Baliga BRV, Kandathil SM, Bhat HP, Vayalil PK (2011). A review of the chemistry and pharmacology of the date fruits (Phoenix dactylifera L.). Food Res. Int., 44: 1812-1822.

Bergmeyer HU, Horder M, Rej R (1985) Approved recommendation on IFCC methods for the measurement of catalytic concentration of enzymes. Part 3, IFCC Method for alanine aminotransferase. J. Clin. Chem. Clin. Biochem. 33: 321-238.

Chobotar B, Danforth HD, Entzeroth R (1993). Ultrastructure observation of host cell invasion by sporozoites of Eimeria papillata in vivo. Parasitol. Res., 79: 15-23.

Dkhil M, Addel-Baki A, Delic D, Wunderlich F, Sies H, Al-Quraishy S (2011a). "Eimeria papillata: Upregulation of specific miRNA-species in the mouse jejunum". Exp. Parasitol., 127: 581-586.

Dkhil MA, Abdel-Baki AS, Wunderlich F, Sies H, Al-Quraishy S (2011b). Anticoccidial and antiinflammatory activity of garlic in murine Eimeria papillata infections. Vet. Parasitol., 175: 66-72.

Epstein E, Kichle FL, Artiss JD (1986) The clinical uses of alkaline phosphatase enzyme. Clin. Lab. Med., 6: 491-505.

Fossati P, Principe $L$ (1982). Serum triglycerides determined colorimetrically with an enzyme that produces hydrogen peroxide. Clin. Chem., 28: 2077-2080.

Jassim SA, Naji MA (2010). In vitro Evaluation of the Antiviral Activity of an Extract of Date Palm (Phoenix dactylifera L.) Pits on a Pseudomonas Phage. Evid. Based Complement Altern. Med., 7: 5762.

Jithendran KP, Bhat KP (1996). Subclinical coccidiosis in Angora rabbits -A field survey in Himachal Pradesh (India). World Rabbit Sci., 4: 29-32.

Joyner RW, Picone J, Veenstra R, Rawling D (1983). Propagation through electrically coupled cells: Effects of regional changes in membrane properties. Circ. Res., 53: 526-534.

Laemmli UK (1970). "Cleavage of structural proteins during the assembly of the head of bacteriophage T4." Nature, 227(259): 680685.

Licois D (2004). Domestic rabbit enteropathies. Proceedings - 8th World Rabbit Congress, Becernl, Puebla, Mexico September 7-10. pp.385403

Mard SA, Jalalvand K, Jafarinejad M, Balochi H, Naseri MK (2010). Evaluation of the antidiabetic and antilipaemic activities of the hydroalcoholic extract of phoenix dactylifera palm leaves and its fractions in alloxan-induced diabetic rats. Malays J. Med. Sci., 17: 413.

Mehlhorn H (2001). Encyclopedic Reference of Parasitology, second ed., vol. 1. Springer Press, Berlin.

Metwaly MS, Dkhil MA, Al-Quarishi S (2011). Renal tissue damage due to Eimeria coecicola infection in rabbits. Afr. J. Microbiol. Res., 5: 1349-1354.

Nagura H, Sumi $Y$ (1988). Immunological functions of the gut, Role of the mucosal immune system. Toxilogic Pathol., 16: 154-164.

Pakandl M, Sewald B, Drouet-Viard F (2006). Invasion of the intestinal tract by sporozoites of Eimeria coecicola and Eimeria intestinalis in naive and immune rabbits. Parasitol. Res., 98: 310-316.

Renaux S, Viard FD, Chanteloup NK, Vern Y, Kerboeuf D, Pakandl M, Coudret $P$ (2001). Tissues and cells involved in the invasion of rabbit intestinal tract by sporozoites of Eimeria coecicola. Parasitol. Res., 
87:98-106.

Saafi EB, Louedi M, Elfeki A, Zakhama A, Najjar MF, Hammami M, Achour $L$ (2011). Protective effect of date palm fruit extract (Phoenix dactylifera L.) on dimethoate induced-oxidative stress in rat liver. Exp. Toxicol. Pathol., 63(5): 433-41.

San Martín-Núñez BV, Ordóñez-Escudero D, Alunda JM (1988). Preventive treatment of rabbit coccidiosis with alpha-difluoromethyl ornithine. Vet. Parasitol., 30: 1-10.

Sablani SS, Shrestha AK, Bhandari BR (2008). A new method of production date powder granules: physicochemical characteristics of powder. J. Food Eng. 87: 416-421.

Saddiq AA, Bawazir AE (2010). "Antimicrobial activity of date palm (Phoenix dactylifera) pits extract and its role in reducing the side effects of methyl prednisolone on some neurotransmitter content in the brain, hormone testosterone and adulthood". ISHS Acta Hortic. IV International Date Palm Conference, p. 882

Schito ML, Barta JR (1997). Nonspecific immune responses and mechanisms of resistance to Eimeria papillata infections in mice. Infect. Immun., 65: 3165-3170.

Schito ML, Barta JR, Chobotar B (1996). Comparison of four murine Eimeria species in immunocompetent and immunodeficient mice. J. Parasitol., 82: 255-262.

Shraideh ZA, Khaled H, Abu-Elteen, Sallal AKJ (1998). Ultrastructural effects of date extract on Candida albicans. Mycopathologia, 142: 119-123.
Taylor MA, Coop RL, Wall RL (2007). Veterinary parasitology, 3rd edn. Blackwell, Ames, pp. 901.

Toulah FH, Ismeel HA, Khan S (2010). Effect of treatment with Neem (Azadirachta indica) compared with Baycox drug on the caecum of chicken experimentally infected with Eimeria tenella. J. Egypt Soc. Parasitol., 40: 93-106.

Trinder P (1969a). "Determination of glucose in blood using glucose oxidase with an alternative oxygen acceptor". Ann. Clin. Biochem., 6: 24-28.

Trinder P (1969b). Enzymatic colorimetric method for cholesterol measurements. Ann. Clin. Biochem., 6: 24-29.

Van Horn L, Annemidy L, Liu K, Liao Y, Ballew C, Kin J, Stamler J (1988). "Serum lipid response to a fat modified, oat meal-enhanced diet. "Prev. Med., 17: 377-386. 